\title{
Students' Perception of Ideal Work - an Agribusiness Sector Case Study
}

\author{
Jarosław UGLIS, Magdalena KOZERA-KOWALSKA \\ Poznań University of Life Sciences, Poznań, Poland \\ \{jaroslaw.uglis, mkozera\}@up.poznan.pl
}

\begin{abstract}
The article is a continuation of the authors' research on the relationship between the level of education and perception of agribusiness as an area of ideal employment and career development. The aim of this research part is to analyse the changes in the students' opinions depending on the level of education they have achieved (fist-cycle studies and second-cycle studies). A detailed analysis included 29 descriptors defining ideal work, as well as the perception of work in the agribusiness sector as the target workplace. The factographic material was collected by means of an auditorium survey, which proved effective in the course of earlier studies. The data that was collected underwent factual verification and statistical analysis. Based on the study, it was concluded that in the students' opinion, the qualities of ideal work should include the following: congruity with one's interests, feeling proud to do this work and achieving economic satisfaction. A welcome feature of ideal work is also friendly atmosphere at the workplace and the possibility to use the knowledge gained over the school period. The research indicated a change of career plans related to the agribusiness sector, i.e. a stronger tendency towards perceiving it as a stage in developing further career.
\end{abstract}

Keywords: Career, Agribusiness, Ideal Work, Perception of Work in Agribusiness.

\section{Introduction}

Both economic theory and economic reality paradigm in building the intellectual capital as a pacemaker development of regions and countries becomes a factor in determining the pace and level of economic development. As assumed by the signaling theory build by Spance [23] the education confirmed by the diploma of graduation acts as one of the main criteria for recruitment and selection of candidates for work [6, 21, 23]. From this point of view being a university graduate is also the information about the probably high level of skills and competences of candidates for work.

An interesting issue of the employee market is the recognition and assessment of students' attitudes as regards perceiving their future work, particularly in agribusiness. Graduates of agricultural and agricultural-economic profile universities realize that a predominant group of future workplaces are connected with agriculture and food economy $[6,5,13,14]$. 
The cognitive value of this study it to emphasizing the role of knowledge needs and its absorption by agribusiness and noticing the specificity of the so-called Generation $\mathrm{Y}$, which entering the labor market becomes the carrier and recipient of this knowledge [4]. Potentially, the employees from this group are mostly young people, born after 1980, growing up in the market economy conditions, in the times when modern technologies were rapidly developing. The students -graduates are also representatives of this generation. For them the digital world is not only an obvious source of information, but also a way of spending time and building social relationships [18]. In contrast to their predecessors, they are less fitted into the reality of the physical sphere of economic processes, but they are inclined to support their work with knowledge, which directly results in the increasing innovativeness of the sectors where they find employment. Their functioning on the labour market reflects the unavoidability of the socio-economic changes taking place not only in agribusiness, but in the whole economy. It has become a challenge for universities responsible for the education of high quality employees, also for agribusiness [5]. Undoubtedly, graduation is a valuable element of building individual intellectual capital. It also gives graduates a better chance of finding a job. In economic practice, especially in agribusiness, the importance of individual intellectual capital of job candidates is still not sufficiently appreciated. However, this is only one of the reasons causing difficulties in finding employment after completing academic education.

The demand for the knowledge contributed by the graduates to the sector is huge, and the human resources training system in Poland correspond to the needs that are reported [3]. It turns out, however, that the constantly deficient supply of highly qualified employees can be related to the graduates' attitudes.

The research conducted by the authors in 2016-2018 seems to confirm this statement. The aim of this paper is to present selected descriptors of ideal work, which are essential to students. The study also presents students' attitudes towards setting up their own businesses as well as treating employment in the agribusiness sector as a stage in the future career.

\section{$2 \quad$ Materials and Methods}

To achieve the aims of the study, the authors made a literature review and conducted a questionnaire survey. They used the auditorium questionnaire method, which is considered to be particularly useful in research conducted among students. The authors adapted the questionnaire used for HoReCa sector studies [1]. The respondents evaluated the total of 29 qualities defining five dimensions of an ideal workplace: work contents, economic benefits, development opportunities, social relations and reputation. In addition, the study included issues connected with the attractiveness of the agritourism sector as a place of work for the students of the Poznan University of Life Sciences.

The survey was conducted in December 2016 among the final term first-cycle studies students of animal science (zootechnics) before their graduation exam. It was repeated among the same students in June 2018 before their final second-cycle studies 
before their graduation exam. Participation in the study was voluntary and anonymous. The empirical material that was collected underwent preliminary evaluation, followed by a statistical independence analysis, using STATISTICA 13.1. The study presented herein is a continuation of the authors' research started in 2016 [8, 9, 10, 22].

\section{Results and Discussion}

The survey was conducted on a sample of thirty seven first-cycle studies students (54.4\% of students at the year) and eighteen second-cycle studies students (54.4\%). In both cases, the majority of each sample were women. The study showed that every third respondent was planning to set up their own business just after finishing university. The results indicate that the respondents are planning to take their future career path into their own hands.

In the course of the study, the students were asked to evaluate 29 features defining their ideal work. The authors used the 7-point Likert (priority) scale, where 1 signified "not a priority", 4 signified "neutral" and 7 - "essential priority". The results are presented in Table 1.

Table 1. Perception of the image of ideal work.

\begin{tabular}{|c|c|c|c|c|c|}
\hline \multirow{2}{*}{ No. } & \multirow{2}{*}{ Descriptors } & \multicolumn{2}{|c|}{$\begin{array}{l}\text { First-cycle studies } \\
\qquad(\mathrm{n}=37)\end{array}$} & \multicolumn{2}{|c|}{$\begin{array}{l}\text { Second-cycle studies } \\
(\mathrm{n}=18)\end{array}$} \\
\hline & & Mean & $\begin{array}{l}\text { Standard } \\
\text { deviation }\end{array}$ & Mean & $\begin{array}{l}\text { Standard } \\
\text { deviation }\end{array}$ \\
\hline 1 & Work according to interests & 6.51 & 0.74 & 6.83 & 0.71 \\
\hline 2 & Work which is challenging & 5.49 & 1.15 & 5.72 & 1.56 \\
\hline 3 & $\begin{array}{l}\text { Gives an opportunity to fully } \\
\text { use the acquired knowledge } \\
\text { and skills }\end{array}$ & 6.24 & 0.98 & 6.72 & 0.57 \\
\hline 4 & $\begin{array}{l}\text { Ensures a considerable } \\
\text { diversity of tasks }\end{array}$ & 6.08 & 0.98 & 6.17 & 1.54 \\
\hline 5 & $\begin{array}{l}\text { Gives an opportunity to } \\
\text { decide how you wish to } \\
\text { perform your duties }\end{array}$ & 6.11 & 0.99 & 6.11 & 1.08 \\
\hline 6 & $\begin{array}{l}\text { Involves a large number and } \\
\text { fast pace of performing } \\
\text { duties }\end{array}$ & 4.89 & 1.24 & 4.50 & 1.82 \\
\hline 7 & $\begin{array}{l}\text { Involves flexible working } \\
\text { time }\end{array}$ & 3.62 & 2.27 & 4.00 & 2.14 \\
\hline 8 & Involves mobility & 3.92 & 1.91 & 4.17 & 2.31 \\
\hline 9 & Easy access by transport & 5.70 & 1.45 & 5.78 & 1.83 \\
\hline 10 & $\begin{array}{l}\text { Is done in an attractive } \\
\text { destination }\end{array}$ & 5.08 & 1.62 & 6.39 & 0.78 \\
\hline 11 & $\begin{array}{ll}\text { Guarantees } & \text { high } \\
\text { remuneration } & \end{array}$ & 6.32 & 0.88 & 6.39 & 1.20 \\
\hline
\end{tabular}




\begin{tabular}{|c|c|c|c|c|c|}
\hline 12 & $\begin{array}{l}\text { Offers a wide range of social } \\
\text { benefits }\end{array}$ & 5.81 & 1.33 & 5.83 & 2.07 \\
\hline 13 & $\begin{array}{l}\text { Provides modern equipment } \\
\text { necessary to perform work } \\
\text { duties }\end{array}$ & 5.51 & 1.24 & 6.28 & 1.45 \\
\hline 14 & $\begin{array}{l}\text { Offers stable employment } \\
\text { conditions }\end{array}$ & 6.14 & 1.29 & 6.50 & 1.04 \\
\hline 15 & $\begin{array}{l}\text { Gives the employee the } \\
\text { possibility to influence the } \\
\text { decisions important for the } \\
\text { company }\end{array}$ & 5.41 & 1.54 & 5.72 & 1.53 \\
\hline 16 & $\begin{array}{l}\text { Ensures a clearly set career / } \\
\text { promotion path }\end{array}$ & 5.86 & 1.46 & 5.94 & 1.80 \\
\hline 17 & $\begin{array}{l}\text { Gives the possibility to raise } \\
\text { qualifications }\end{array}$ & 6.11 & 1.13 & 6.50 & 1.25 \\
\hline 18 & $\begin{array}{l}\text { Provides the possibility of } \\
\text { long-term professional } \\
\text { development at a given } \\
\text { company }\end{array}$ & 5.83 & 1.40 & 6.44 & 1.25 \\
\hline 19 & $\begin{array}{l}\text { Guarantees learning skills } \\
\text { useful at other workplaces }\end{array}$ & 5.59 & 1.34 & 6.44 & 0.70 \\
\hline 20 & $\begin{array}{l}\text { Allows the employee to } \\
\text { combine work duties with } \\
\text { private life }\end{array}$ & 5.92 & 1.40 & 5.83 & 1.72 \\
\hline 21 & $\begin{array}{l}\text { Friendly atmosphere at the } \\
\text { place of work }\end{array}$ & 6.32 & 1.13 & 6.78 & 0.73 \\
\hline 22 & $\begin{array}{l}\text { Ensures respectful treatment } \\
\text { by clients and co-workers }\end{array}$ & 6.24 & 1.21 & 6.39 & 1.04 \\
\hline 23 & $\begin{array}{l}\text { Gives a sense of support } \\
\text { from co-workers }\end{array}$ & 6.24 & 1.16 & 6.44 & 0.86 \\
\hline 24 & $\begin{array}{l}\text { It is performed together with } \\
\text { competent co-workers }\end{array}$ & 6.11 & 1.26 & 6.22 & 1.06 \\
\hline 25 & $\begin{array}{l}\text { Gives a sense of belonging } \\
\text { and integration with the } \\
\text { team }\end{array}$ & 6.16 & 0.99 & 5.78 & 1.44 \\
\hline 26 & $\begin{array}{l}\text { Involves offering high } \\
\text { quality products/services }\end{array}$ & 5.57 & 1.46 & 6.11 & 1.18 \\
\hline 27 & $\begin{array}{l}\text { Enjoys considerable social } \\
\text { prestige }\end{array}$ & 5.32 & 1.40 & 5.61 & 1.69 \\
\hline 28 & $\begin{array}{l}\text { Gives a sense of pride with } \\
\text { performing work duties }\end{array}$ & 6.38 & 0.98 & 6.56 & 0.70 \\
\hline 29 & $\begin{array}{l}\text { Work is done at an } \\
\text { enterprise which serves the } \\
\text { local community }\end{array}$ & 4.62 & 1.60 & 4.00 & 2.22 \\
\hline
\end{tabular}


The analysis of the results showed that in the opinion of the first-cycle studies students, ideal work should match their interests (6.51), provide them with a sense of pride with their duties (6.38) and guarantee high remuneration (6.32). At the same time, the three most important qualities of ideal work mentioned by the second-cycle studies students included matching their interests (6.83), friendly atmosphere at the workplace (6.78) and having a job giving an opportunity to make use of the knowledge and skills gained at the university. The second-cycle studies students put high remuneration at the 10th place, allocating it 6.39 points. The descriptors which were least important for both groups of respondents included: (6) the fast pace of fulfilling one's responsibilities, (7) flexible working time, (8) mobility and (29) a job at an enterprise working for the benefit of the local community.

In order to check whether the points allocated to individual qualities vary depending on the level of studies, the authors applied the U Mann-Whitney test and a test from the Wald-Wolfowitz series. The results of the former clearly pointed to a statistically significant $(p<0.05)$ differentiation of the allocated points in the case of seven descriptors: $1,10,13,17,18,19$ and 21 . The other test indicated statistically significant differentiation of the allocated points in the case of four descriptors: 7, 9, 12, 21. Based on the results that were achieved, it should be concluded that the respondents differ most in their evaluation of the features connected with career development opportunities.

In the further part of the study, the analysed qualities were aggregated into five variables: work contents (1-10), economic benefits (11-14), career prospects (15-19) social relations (20-25) and reputation (26-29), using the arithmetical mean of the descriptors. The results of the aggregation are presented in Figure 1 and Figure 2.

Analysing the results presented in these charts, we can clearly see that the calculated mean values for individual variables differ one from another. It was also confirmed by the Kruskal-Wallis test $(\mathrm{p}<0.01)$ in both groups of respondents. More detailed analyses showed that a statistically significant differentiation of the allocated points regarded only the mean values for the economic benefits variable ( $U$ Mann-Whitney, $p<0.05$ ); in the remaining cases a significant differentiation was not observed. 


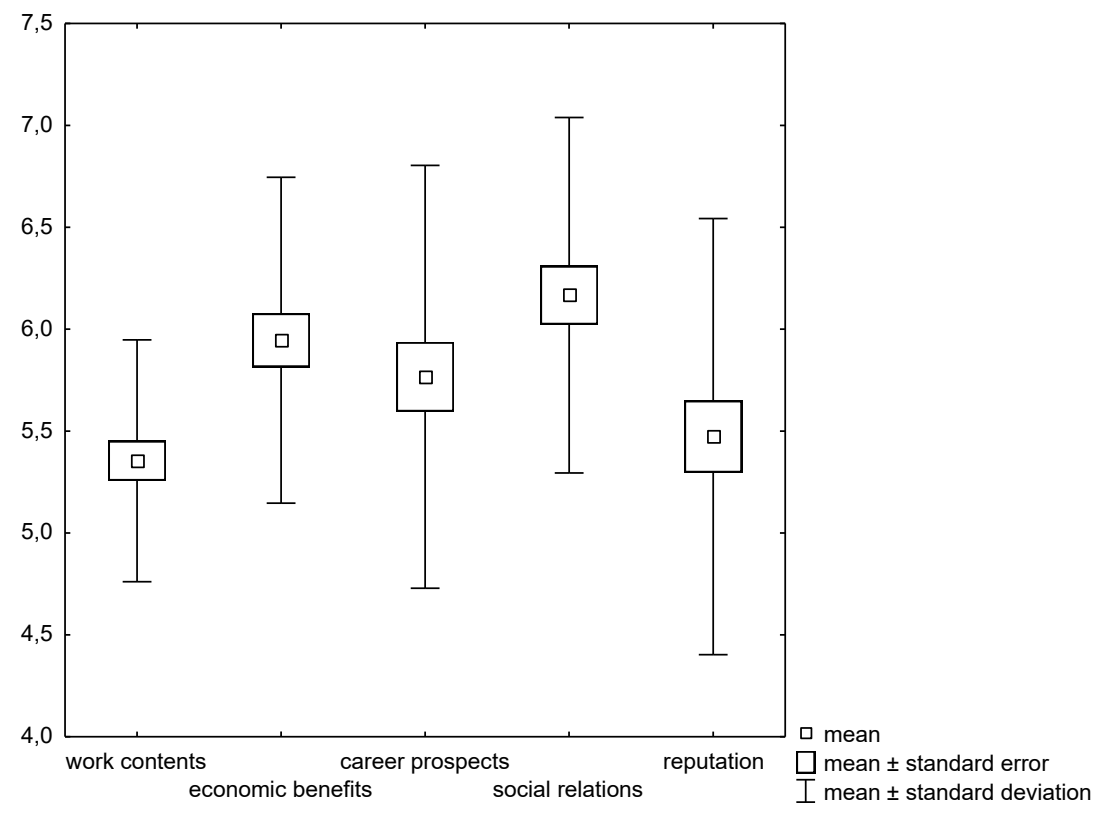

Fig. 1. Students' expectations as regards an ideal workplace after completing first-cycle studies.

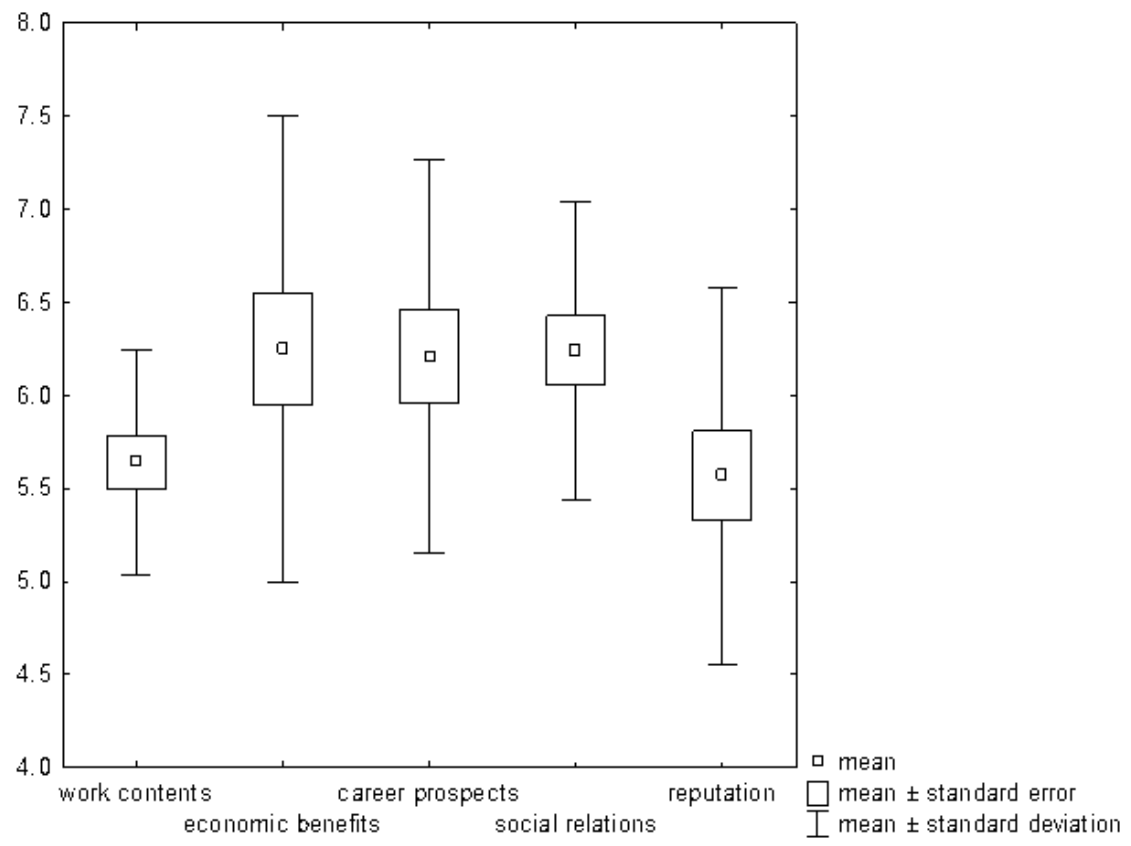

Fig.2. Students' expectations as regards an ideal workplace after completing second-cycle studies. 
At the last stage of the study, the students were asked for an opinion about the attractiveness of work in the agribusiness sector (Fig. 3). Undoubtedly, agribusiness is a rapidly growing sector of business initiative in many countries around the world [11]. The respondents tended to agree with the statement that work in agribusiness would be an interesting stage in their career rather than the target permanent workplace.

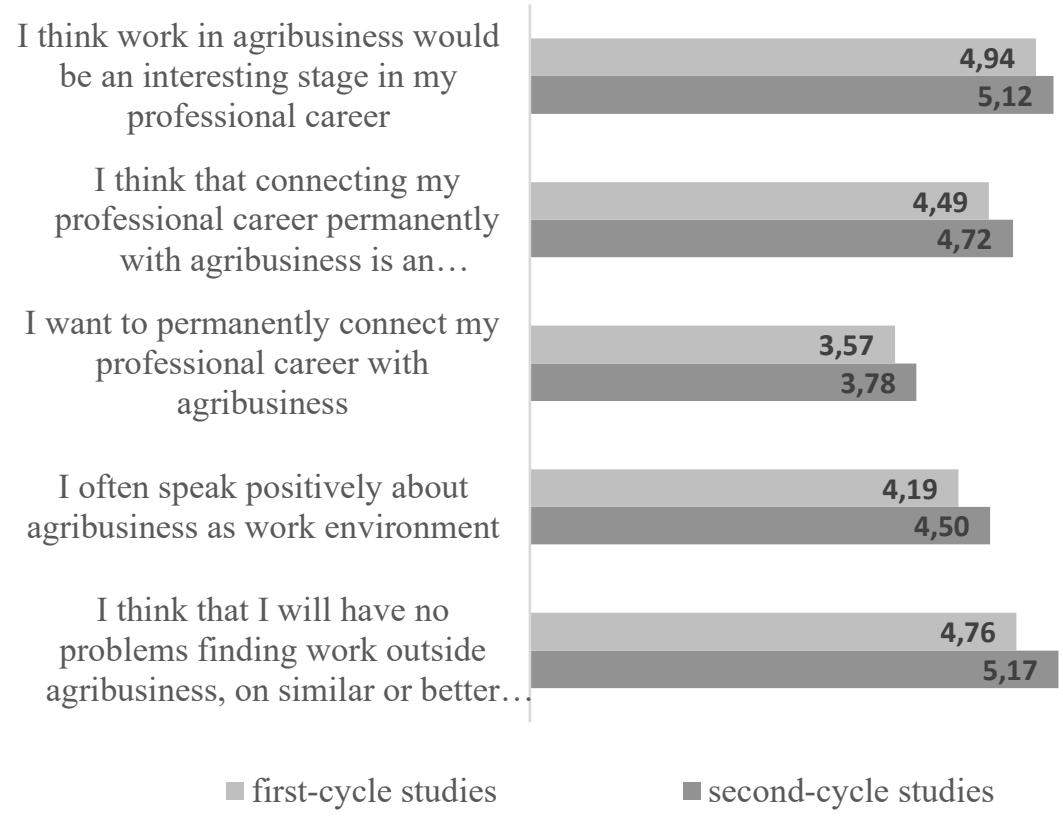

Fig. 3. Attitude to connecting career with agribusiness.

The respondents perceive agribusiness as a potential workplace as they express positive opinions about this sector. However, a great majority believe that they will easily find work in other sectors. The results achieved in this research corresponds to the results of other authors. They analyse the job offer of agribusiness addressed to the students from various point of views, i.e. industry [20], the existing education system [12], or from the student's perspective $[19,19]$. They are also the part of another studies related to the students possessing or not the required competences [7]. It should be noted that the similar research is also carried out by scientists from other countries, eg Sweden, USA $[2,13,14]$. However, existing surveys largely ignore the agribusiness sector as a potential workplace for graduated. 


\section{Conclusions}

Despite the relatively effective system of vocational education and higher education, the demand for qualified workers generated by the agribusiness sector still remains unsatisfied. The causes of this situation should be sought in the attitudes of university graduates, i.e. the prospective employees, whose opinions about work in this sector are highly diversified. It is related to an imagination of the first, ideal work, as well as the perception of agribusiness as a stage in career development. The research that was conducted showed that graduates highly evaluate work in the sector, but they tend to agree more with the statement that it would be an interesting stage in their career rather than the target permanent workplace. This opinion was expressed by both, first- and second-cycle studies students.

As regards perceiving work as ideal, it was interesting to observe that second-cycle studies graduates value work which matches their interests, friendly atmosphere at the workplace, and a job which gives them an opportunity to use the knowledge and skills they have gained at the university more than economic benefits. Such a hierarchy of qualities is an optimistic forecast for the agribusiness sector, as it indicates that the studied group of potential employees are going to engage in work in agribusiness for reasons other than financial, which are among the strongest motivators of human activity.

\section{References}

1. Bednarska, M.: Kariera zawodowa w hotelarstwie w opinii studentów - implikacje dla współpracy praktyki gospodarczej z systemem edukacji. Studia Oeconomica Posnaniensia, vol. 2, no. 1(262), 152-167 (2014).

2. Briers, G.E., Shinn G.C., Nguyen, A.N.: Through students' eyes: Perceptions and aspirations of college of agriculture and life science students regarding international educational experiences. Journal of International Agricultural and Extension Education, vol.17 no 2, 5 20 (2010).

3. Gabińska, C. G.: Kształcenie na rzecz przedsiębiorczości na obszarach wiejskich. Przedsiębiorczość-Edukacja, 8, 259-277 (2012).

4. Hayami, Y., Ruttan, V.W.: Agricultural development: an international perspective. The Johns Hopkins Press, Baltimore (1971).

5. Hobbs, P.R.: Conservation agriculture: what is it and why is it important for future sustainable food production? The Journal of Agricultural Science, vol. 145 no. 2, 127-137 (2007).

6. Hopkins, E.: Job Market Signaling of Relative Position, or Becker Married to Spence. Journal of the European Economic Association, vol. 10, no. 2, 290-322 (2012). DOI: 10.1111/j.1542-4774.2010.01047.x.

7. Kavanagh, M.H., Drennan, L.: What skills and attributes does an accounting graduate need? Evidence from student perceptions and employer expectations. Accounting \& Finance, 48(2), 279-300 (2008).

8. Kozera-Kowalska M. ,Uglis J.: Kariera zawodowa w agrobiznesie w opinii studentów Uniwersytetu Przyrodniczego w Poznaniu - przyczynek do badań. In: Nowicki, R.G., Kosmaczewska, J., Barczak, M. (eds.) Przedsiębiorczość na obszarach wiejskich - 
koncepcje, realizacje, kierunki rozwoju, pp. 107-120, Wydawnictwo Uczelniane Wyższej Szkoły Gospodarki, Bydgoszcz (2016).

9. Kozera-Kowalska M., Uglis J.: Kształcenie kadr dla turystyki wiejskiej. In: Jęczmyk, A., Uglis, J., Maćkowiak, M. (eds.) Turystyka wiejska. Tom 1. Zagadnienia ekonomiczne i marketingowe, pp. 32-39, Wydawnictwo Wieś Jutra, Poznań (2016).

10. Kozera-Kowalska M., Uglis J.: Postrzeganie kariery zawodowej w agrobiznesie przez studentów Uniwersytetu Przyrodniczego w Poznaniu- studium przypadku. RN SERiA t. XIX, z. 2, 142-149 (2017).

11. Kozera-Kowalska, M., Uglis, J.: Diferentiation of employment in agriculture - case study the Viserad Group countries. In: Jedlicka, P, Maresova, P, Soukal, I. (eds.), proceedings paper of the 15th International Scientific Conference on Hradec Economic Days, pp. 469477. University Hradec Kralove, Hradec Kralove (2017).

12. Litzenberg, K.K., Gorman, W.D., Schneider, V.E.: Academic and professional programs in agribusiness. American Journal of Agricultural Economics, 65(5), 1060-1064 (1983).

13. Ng, T.W., Feldman, D.C. How broadly does education contribute to job performance?. Personnel psychology, 62(1), 89-134 (2009).

14. Nilsson, P.A., Ripmeester, N.: International student expectations: Career opportunities and employability. Journal of International Students, 6(2), 614-631 (2016).

15. Norwood, F.B., Henneberry, S.R.: Show me the money! The value of college graduate attributes as expressed by employers and perceived by students. American Journal of Agricultural Economics, 88(2), 484-498 (2006).

16. Orczykowska, A.: Szkolnictwo wyższe a wymagania rynku pracy. Nauka i Szkolnictwo Wyższe, 2(28), 49-64 (2006).

17. Piróg, D.: Absolwenci szkół wyższych na rynku pracy $\mathrm{w}$ warunkach kryzysu. Przedsiębiorczość-Edukacja, 9, 302-316 (2013).

18. Pretty, J., et al.: The top 100 questions of importance to the future of global agriculture. International Journal of Agricultural Sustainability, vol. 8, no. 4, 219-236 (2010). DOI: 10.3763/ijas.2010.0534.

19. Qenani, E., MacDougall, N., Sexton, C.: An empirical study of self-perceived employability: Improving the prospects for student employment success in an uncertain environment. Active Learning in Higher Education, 15(3), 199-213 (2014).

20. Scanlon, D.C., Bruening, T.H., Cordero, A.: An industry perspective on changes needed in agricultural education curricula. Journal of Agricultural Education, 37, 17-23 (1996).

21. Spence, M.: Job Market Signalling. The Quarterly Journal of Economics, vol. 87, no. 3, 355-374 (1973).

22. Uglis J., Kozera-Kowalska M., Łopuszyńska Z.: Staff education system for agribusiness case study Poznań University of Life Sciences, Poland. In: Horská E. et al. (eds), Proceedings of International Scientific Days 2018. "Towards Productive, Sustainable and Resilient Global Agriculture and Food Systems", pp. 2072-2082, Wolters Kluwer ČR, (2018).

23. Wilkin, Ch.L., Connelly C.E.: Do I Look Like Someone Who Cares? Recruiters' Ratings of Applicants' Paid and Volunteer Experience. International Journal of Selection and Assessment, vol. 20, 308-318 (2012). 